\title{
GAMBARAN PELAKSANAAN SISTEM RUJUKAN PUSKESMAS DI DAERAH KEPULAUAN
}

\section{DEMONSTATION OF REFERRAL SYSTEM ARCHIPELAGO IN HEALTH CENTER}

\author{
Meistvin Welembuntu, Iswanto Gobel \\ Program Studi Keperawatan, Jurusan Kesehatan \\ Email: meistvin@yahoo.com
}

\begin{abstract}
Abstrak: Salah satu prioritas reformasi kesehatan adalah meningkatkan dan pemerataan pelayanan yang bermutu bagi masyarakat di daerah terpencil dan kepulauan. Salah satu permasalahan di daerah kepulauan dan daerah terluar seperti pada wilayah kerja Puskesmas Nusa Tabukan adalah sistem rujukan dari Puskesmas menuju Rumah Sakit Tipe C yaitu RSD Liun Kendage Tahuna. Oleh karena itu perlunya suatu studi untuk memiliki gambaran pelaksanaan sistem rujukan puskesmas di daerah Kepulauan. Penelitian ini merupakan penelitian deskriptif, dengan rancang bangun cross sectional. Penelitian ini dilakukan di kampung Nipa, Pulau Nusa yang merupakan wilayah kerja Puskesmas Nusa Tabukan. Populasi dalam penelitian ini adalah seluruh masyarakat yang pernah mendapatkan pelayanan rujukan berupa pendampingan oleh perawat atau petugas kesehatan rerata dalam 3 tahun terakhir dengan jumlah sampel sebanyak 59 orang. Hasil Penelitian ini menunjukkan pelaksanaan rujukan pasien di wilayah kepulauan Puskesmas Nusa Tabukan berjalan dengan baik walaupun belum terdapat perahu/ambulance laut yang terstandar dan masih menggunakan perahu komersil/masyarakat yang dimodifikasi sementara untuk SOP pelaksanaan rujukan secara baku belum ditetapkan dan masih bersifat fleksibel. Diharapkan kerjasama antara pihak pemerintah daerah melalui Dinas Kesehatan dan perangkat kampung dalam memfasilitasi transportasi rujukan pasien.
\end{abstract}

Kata Kunci: Rujukan, Puskesmas, Kepulauan.

\begin{abstract}
One of the priorities for health reformation is to improve and equal health services to the community in remote areas and archipelagos. One of the problems in the islands and outermost areas, for example in the working area of the Nusa Tabukan Health Center, is the referral system from the Public Health to Type C Hospital, namely RSD Liun Kendage Tahuna. Therefore, a study is needed to have an overview of the implementation of the Public Health center referral system in the Archipelago area. This research was a descriptive study, with a cross-sectional design. This research was conducted in Nusa Utara Island, which is the working area of the Nusa Tabukan Health Center. The population of this study was all people who had received referral services in the form of assistance by nurses or health workers in the last 3 years on average with a total sample of 59 participants. The results of this study indicate that the implementation of patient referrals in the islands of Nusa Tabukan Health Center is going well even though there is no standardized boat/ambulance and still uses modified commercial/community boats, while the operating standard procedure (SOP )referral has not been established and it depends on the situation. This research recommends that cooperation between local government through the Health Department and village officials should facilitate the transportation of the patient.
\end{abstract}

Keywords: Referral, Health Centre, Archipelago

\section{PENDAHULUAN}

Puskesmas merupakan suatu fasilitas pelayanan kesehatan memiliki peran yang sangat strategis dalam upaya mempercepat peningkatan derajat kesehatan masyarakat Indonesia, peran strategis ini diperoleh karena puskesmas adalah fasilitas kesehatan Tingkat Pertama yang menjadi tujuan kedatangan utama pasien dan keluarga saat membutuhkan layanan kesehatan. Pelayanan kesehatan di Indonesia dilaksanakan secara berjenjang sesuai dengan kebutuhan medis, dimulai 
dari pelayanan kesehatan fasilitas tingkat 1 hingga berlanjut ke fasilitas kesehatan tingkat III (Ali, 2015). Puskesmas bertanggung jawab untuk menyelenggarakan pelayanan kesehatan tingkat pertama secara menyeluruh, terpadu, dan berkesinambungan. Pelayanan kesehatan tingkat pertama yang menjadi tanggung jawab puskesmas yaitu pelayanan kesehatan perorangan dan pelayanan kesehatan masyarakat (Nurlinawati \& Werni, 2019)

Ada beberapa hal yang berperan dalam kepuasan pasien antara lain pelayanan dokter dan perawat, bidan, dan tenaga kesehatan lainya, kualitas ruangan berobat yang diberikan puskesmas serta ketersediaan sarana penunjang medis dan non medis. Jumlah pekerja di Puskesmas Nusa Tabukan Berjumlah 22 orang yang terdiri dari 2 orang dokter, 11 orang perawat, 1 orang sanitasi,1 orang gizi,5 orang administrasi,1 orang bidan, 1 orang Teknik informasi.

Puskesmas Nusa Tabukan merupakan salah satu puskesmas yang terletak di salah satu pulau yang berada di Kabupaten Kepulauan Sangihe. Berdasarkan letak geografisnya jarak antara Puskesmas Nusa Tabukan menuju RS rujukan terdekat yaitu RSD Liunkendage Tahuna membutuhkan perjalanan laut kurang lebih 2 jam disaat lautan teduh, setelah itu dilanjutan dengan perjalanan darat sejauh 17 KM (50 menit menggunakan Mobil). Proses rujukan yang panjang ini membutuhkan suatu sistem layanan yang terpadu.

Rujukan ini diberikan kepada pasien JKN jika puskesmas tidak dapat memberikan pelayanan kesehatan sesuai dengan kebutuhan pasien karena keterbatasan fasilitas, pelayanan dan ketenagaan, serta diagnosis pasien diluar 155 diagnosis yang harus dilayani di puskesmas (BPJS Kesehatan, 2014). Pasien yang dirujuk oleh Puskesmas merupakan pasien dalam status Gawat atau membutuhkan pemeriksaan dan prosedur lanjut. Keadaan pasien yang mengancam nyawa ini akan lebih beresiko jika sistem rujukan puskesmas ke fasilitas kesehatan Tingkat 2 memerlukan prosedur yang panjang dengan tambahan biaya dan waktu.

Berdasarkan uraian di atas maka perlu untuk melakukan penelitian mengenai Gambaran Pelaksanaan Sistem Rujukan Puskesmas di daerah kepulauan.

\section{METODE PENELITIAN}

Penelitian ini merupakan penelitian deskriptif, dengan rancang bangun cross sectional yang bertujuan untuk mendapatkan informasi tentang pelaksanaan rujukan di Puskesmas Nusa Tabukan tanpa memberikan intervensi pada pelaksanaan sistem tersebut. Penelitian ini dilaksanakan pada 26 Juli - 30 Agustus 2021.

Populasi dalam penelitian ini adalah seluruh masyarakat yang pernah mendapatkan pelayanan rujukan berupa pendampingan oleh perawat atau petugas kesehatan rerata dalam 3 tahun terakhir yakni sebanyak 70 orang. Teknik pengambilan sampel pada penelitian ini yaitu menggunakan purposive sampling sedangkan perhitungan besar sampel menggunakan rumus Slovin sehingga jumlah sampel 59 orang.

\section{HASIL DAN PEMBAHASAN}

Berikut ini disajikan hasil penelitian yang telah dilaksanakan antara lain sebagai berikut:

1. Karakteristik Responden Tabel 1 menunjukan sebagian besar responden berjenis kelamin perempuan sejumlah 35 orang $(59,3 \%)$ dan berdasarkan tempat tinggal terbanyak berasal dari kampung Nanedakele yakni 22 orang (37,3 \%), sementara kondisi pasien saat dirujuk sebanyak 40 orang $(67,8)$ dalam kondisi darurat dan hampir seluruhnya pasien memiliki Jaminan Sosial berupa BPJS (96,6\%). 


\section{Pelaksanaan Rujukan}

Tabel berikut merupakan pelaksanaan rujukan di Puskesmas Nusa Tabukan dilihat dari aspek layanan pestugas kesehatan beserta layanan fasilitas rujukan berupa alat transportasi dan kelengkapannya.

Tabel 2. menginformasikan proses rujukan yang berlangsung di wilayah PKM Nusa Tabukan sebanyak 55,9 \% (33 orang) masyarakat menyatakan baik sementara hanya $49 \%$ (26 orang) menyatakan cukup dan tidak ada masyarakat yang menyatakan

\begin{tabular}{ccc}
\hline \multicolumn{3}{c}{ Tabel 1. Karakteristik Responden Penelitian } \\
\hline $\begin{array}{c}\text { Karakteristik } \\
\text { Responden }\end{array}$ & $\begin{array}{c}\text { Jumlah } \\
\text { (n) }\end{array}$ & Persentasi (\%) \\
\hline
\end{tabular}

\section{Jenis Kelamin}

Laki-laki 24 40,7

Perempuan

35

59,3

\begin{tabular}{lcc}
\hline Alamat (Pulau) & & \\
Nanedakele & 22 & 37,3 \\
Nipa & 17 & 28,8 \\
Bukide & 5 & 8,5 \\
Dalaweng & 15 & 25,4 \\
\hline
\end{tabular}

\section{Kondisi saat dirujuk}

$\begin{array}{lll}\text { Darurat } & 40 & 67,8\end{array}$

Tidak Darurat

19

32,2

\section{Asuransi BPJS}

\begin{tabular}{lcc} 
Ada & 57 & 96,6 \\
Tidak ada & 2 & 3,4 \\
\hline Total & $\mathbf{5 9}$ & $\mathbf{1 0 0 , 0}$ \\
\hline
\end{tabular}

proses rujukan kurang.
3. Hubungan Antara Kondisi Pasien dan Proses Rujukan

Tabel 2. Gambaran Pelaksanaan Rujukan di Puskesmas Nusa Tabukan Tahun 2021

\begin{tabular}{lcc}
\hline Proses rujukan & Jumlah (n) & Persentasi (\%) \\
\hline Baik & 33 & 55,9 \\
Cukup & 26 & 49,1 \\
Kurang & 0 & 0 \\
\hline \multicolumn{1}{c}{ Total } & 59 & 100 \\
\hline
\end{tabular}

Tabel. 3 Hubungan Antara Kondisi Kedaruratan Pasien Saat dirujuk dengan Proses Rujukan

\begin{tabular}{ccccc} 
& Proses Rujukan & $\begin{array}{c}\text { Nilai } \\
\mathbf{p}\end{array}$ \\
\hline Baik & Cukup & \\
\hline n & $\%$ & n & $\%$
\end{tabular}

\begin{tabular}{lllllll}
\hline $\begin{array}{l}\text { Kondisi } \\
\text { Kedarura } \\
\text { tan }\end{array}$ & $\begin{array}{l}\text { Daru } \\
\text { rat }\end{array}$ & 29 & 72,5 & 1 & 27,5 & \\
& Tida & & & & & $\mathbf{0 , 0 0 2}$ \\
& $\begin{array}{l}\text { k } \\
\text { Daru } \\
\text { rat }\end{array}$ & 5 & 26,3 & 4 & 73,7 & \\
& & & & & & \\
& Total & 34 & 57,6 & 2 & 42,4 & 100 \\
& & & & 5 & & \\
\hline
\end{tabular}

*Uji Chi-Square

Tabel 3 menyajikan hasil sebagian besar pasien yang dirujuk dalam kondisi darurat mendapatkan proses rujukan yang baik yakni sebanyak 20 orang $(72,5 \%)$, sementara kondisi yang terbalik pada pasien yang tidak darurat sebagian besar mendapatkan proses rujukan cukup yakni sebanyak 14 orang $(73,7 \%)$. 
Pada analisis bivariate dengan menggunakan uji chi square didapatkan nilai $\mathrm{p}=0,002$ (kurang dari $0,05)$ yang artinya terdapat hubungan yang bermakna antara kondisi kedaruratan pasien saat dirujuk dengan proses rujukan yang dilakukan berdasarkan persepsi pasien dan keluarga.

Sistem Rujukan pelayanan kesehatan merupakan penyelenggaraan pelayanan kesehatan yang mengatur pelimpahan tugas dan tanggung jawab pelayanan kesehatan secara timbal balik baik vertikal maupun horizontal dimana penyelenggaraannya dilakukan secara berjenjang mulai dari pelayanan tingkat pertama di Puskesmas sampai dengan pelayanan tingkat ketiga di Rumah Sakit Pusat (Permenkes RI no 1 tahun 2012).

Puskesmas Nusa Tabukan merupakan Fasilitas Kesehatan Tingkat pertama yang memberikan pelayanan di wilayah kerja Kecamatan Nusa Tabukan dimana karakteristik kewilayahannya berorientasi laut, selain pelayanan dasar Puskesmas juga memberikan pelayanan lanjutan berupa proses rujukan ke Faskes tingkat kedua yakni RSUD Liunkendage Tahuna.

Hasil penelitian yang telah dilakukan didapatkan proses rujukan mendapatkan respon yang baik oleh sebagian besar masyarakat, proses rujukan meliputi alur pelayanan, penjelasan proses rujukan, ketersedian fasilitas rujukan berupa transportasi dan peralatan pendamping rujukan serta pelayanan pendampingan diatas kapal/perahu.

Alur pelayanan yang diberikan oleh Puskesmas dilakukan secara sistimatis mulai dari indikasi yang mewajibkan pasien harus dirujuk sampai dengan penjelasan yang diberikan kepada pasien dan keluarga, penjelasan yang baik akan sangat berpengaruh terhadap pelayanan yang diberikan terutama dalam menurunkan kecemasan pasien apalagi bila kondisi pasien dalam keadaan kritis (Agustin, 2020)

Ketersediaan fasilitas sarana transportasi laut berupa ambulance belum tersedia di Puskesmas begitu juga dengan peralatan yang ada didalamnya tentu saja juga belum ada. dalam melakukan rujukan pihak Puskesmas melalui Kepala Puskesmas Nusa secara swadaya menyiapkan perahu yang dimodifikasi penggunaannya untuk transportasi pasien, walaupun kondisi perahu yang ada belum sesuai standar namun hal tersebut sangat membantu dalam pelayanan, sebuah pepatah yang disampaikan oleh kepala Puskesmas “Tak ada rotan akarpun jadi”.

Gambar 2. Perahu masyarakat yang sering digunakan saat merujuk pasien
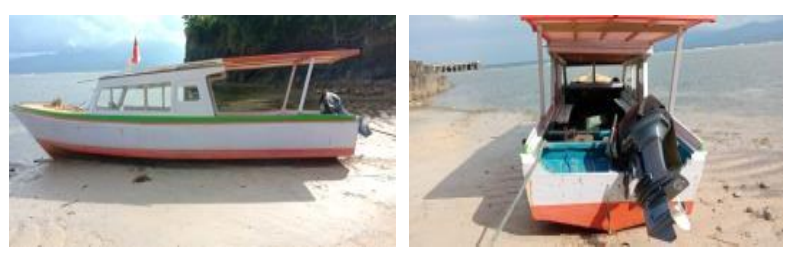

Proses pendampingan dilakukan oleh perawat saat perjalanan menuju lokasi rujukan dimana pada saat tersebut perawat membawa peralatan minimal antara lain Tensi meter, Thermo meter, Stetoskop, Infus Set \& Syiring, sementara peralatan penting lainnya berupa Tabung Oksigen belum tersedia di Puskesmas, khusus untuk perjalanan darat berupa mobil ambulance pihak Puskesmas juga belum memiliki namun disiasati dengan melakukan kerjasama berupa pinjam pakai dengan RS Liung Paduli dan tak jarang pula pasien dibawa dengan menggunakan kenderaan umum.

Kondisi diatas sangat berisiko terjadinya dampak buruk bagi pasien berupa kecacatan ataupun kematian apalagi pada pasien dengan kondisi darurat (67,8 \% responden) tentunya tindakan tertentu tidak dapat dilakukan seperti pemberian oksigen, suction dan tindakan lainnya padahal prinsip penanganan gawat darurat harus dilakukan secara cepat dan tepat ditempat 
kejadian tentunya juga dengan menggunaakan alat yang terstandar dan oleh orang yang kompeten (Permenkes no 19 tahun 2016).

Hasil evaluasi yang dilakukan oleh Zaenab pada Provinsi Kepulauan Riau tahun 2012 menyatakan bahwa masalah dan tantangan puskesmas serta Rumah Sakit Umum Daerah dalam mendukung sistem rujukan maternal ialah keterbatasan sumber daya seperti sarana dan peralatan, Tim yang kurang bekerjasama antar level rujukan, belum lengkapnya SOP rujukan, lemahnya sistem informasi dan alur rujukan yang by pass.

Hasil penelitian pada uji bivariate antara kondisi darurat dengan proses rujukan yang diberikan didapatkan nilai alfa 0,002 yang artinya terdapat hubungan yang signifikan antara pelayanan yang diberikan dengan kondisi kedaruratan pasien dimana pada pasien darurat pelayanan yang diberikan sebagian besar baik dibandingkan pada pasien tidak darurat, hal tersebut memberikan makna bahwa walaupun ketersediaan sarana dan prasarana yang kurang memadai namun pelayanan yang diberikan oleh perawat sudah maksimal dibuktikan dengan penilaian masyarakat.

Studi di Desa Nggele kabupaten Pulau Taliabu Provinsi Maluku Utara juga menunjukkan bahwa masyarakat memiliki persepsi yang positif terhadap pelayanan yang diberikan oleh puskesmas Nggele yang merupakan puskesmas yang berlokasi di kepulauan dalam hal pelayanan administrasi dalam melakukan pelayanan baik dari pemeriksaan maupun pemberian informasi dengan jelas kepada pasien serta tindakan yang baik yang selalu dijaga oleh pegawai dan kecepatan dalam melakukan pekerjaan. Dalam hal layanan rujukan apabila pasien yang datang di puskesmas kondisinya tidak bisa ditangani, pihak puskesmas langsung memberikan rujukan dan pasien serta keluarga memahami infomasi yang diberikan.
Walaupun Puskesmas Nggele juga memiliki tantangan dalam hal kelengkapan sarana dan prasarana (Juahepa \& Mane, 2018).

Sistem rujukan maternal dan neonatal dengan kondisi darurat di provinsi Papua dan Maluku juga menunjukkan tantangan yang sama yang dihadapi oleh puskesmas kepulauan lainnya. Pelayanan belum maksimal diberikan karena keberadaan tenaga medis yang belum menetap, ketersediaan dan kecukupan alat kesehatan dan bahan habis pakai yang belum memadai, pembiayaan yang masih memberatkan pasien terutama untuk biaya transportasi tenaga pengantar pasien yang membutuhkan biaya besar karena kondisi geografis daerah kepulauan ( Lestari, Sugiharti, Mujiati, 2018).

Alur rujukan lewat darat dan laut merupakan alur rujukan khas kepulauan. Kondisi pasien yang gawat darurat dan kritis menambahkan kompleksitas rujukan pada daerah kepulauan. Suatu proses yang membutuhkan kesiapan ambulans, peralatan lengkap, pendamping, obat-obatan untuk mendukung perjalanan pasien hingga ke rumah sakit rujukan dengan selamat. Pemerintah Daerah memiliki peranan yang sangat penting dalam mendukung pelayanan kesehatan.

Untuk meningkatkan pelayanan rujukan, Pemerintah Kabupaten Lingga Provinsi kepulauan Riau mengeluarkan upaya kebijakan dalam meningkatkan sistem rujukan. Kebijakan yang dikeluarkan oleh pemerintah yaitu dari sisi demand (biaya pengobatan) dan sisi supply (sistem yang mendukung pelayanan kesehatan(Luti, dkk (2012).

Demikian halnya dengan Pemerintah Aceh. Untuk menjawab kebutuhan layanan rujukan daerah kepulauan maka Pemerintah Aceh menyediakan layanan ambulans udara. Layanan ini sangat dirasakan manfaatnya oleh masyarakat Aceh. Waktu tempuh pasien berkurang drastis. Pasien dari daerah Simeuleu 
yang merupakan daerah yang paling sering merujuk pasien, membutuhkan perjalanan laut 9 jam dan dilanjutkan perjalanan darat selama 8 jam baru tiba di Banda Aceh. Saat menggunakan ambulance udara untuk merujuk, hanya membutuhkan waktu 2 jam penerbangan. Waktu yang lebih singkat ke tempat layanan dengan ketersediaan sarana dan prasarana yang memadai berdampak pada outcome pasien ( Silvalila, 2019).

\section{KESIMPULAN}

Pelaksanaan rujukan pasien di wilayah kepulauan Puskesmas Nusa Tabukan berjalan dengan baik walaupun belum terdapat perahu/ambulance laut yang terstandar dan masih menggunakan perahu komersil/masyarakat yang dimodifikasi sementara untuk SOP pelaksanaan rujukan secara baku belum ditetapkan dan masih bersifat fleksibel.

\section{DAFTAR RUJUKAN}

Agustin, W. R. (2020). Hubungan Caring Perawat Dengan Tingkat Kecemasan Keluarga Pasien Koma Di Ruang Intensif. Jurnal Ilmiah Kesehatan Media Husada, 9(1), 21-27.

Ali, F. A. (2015). Analisis pelaksanaan rujukan rawat jalan tingkat pertama peserta program Jaminan Kesehatan Nasional (JKN) di Puskesmas Siko dan Puskesmas Kalumata Kota Ternate tahun 2014. Jikmu, 5(3).

BPJS Kesehatan, 2014. Peraturan Badan Penyelenggaraan Jaminan Sosial Kesehatan Nomor 1 Tahun 2014 Tentang Penyelenggaraan Jaminan Kesehatan. S.I: BPJS Kesehatan.
Juahaepa, Dewi Anggraini, Malo Ode Mane, "Persepsi Masyarakat terhadap Pelayanan Puskesmas (Studi di Desa Nggele Kecamatan Taliabu Barat Laut Kabupaten Pulau Taliabu Provinsi Maluku Utara)." Jurnal Neo Societal, vol. 3, no. 1, 19 Jan. 2018, doi:10.33772/jns.v3i1.3575.

Lestary, H., Sugiharti, S., \& Mujiati, M. (2018). Sistem Rujukan Maternal dan Neonatal di Daerah Kepulauan (Studi Kasus di Provinsi Papua dan Maluku). Media Penelitian dan Pengembangan Kesehatan, 28(2), 83-94.

Luti, I., Hasanbasri, M., \& Lazuardi, L. (2012). Kebijakan pemerintah daerah dalam meningkatkan sistem rujukan kesehatan daerah kepulauan di kabupaten Lingga Provinsi Kepulauan Riau. Jurnal Kebijakan Kesehatan Indonesia: JKKI, 1(1).

Nurlinawati,I., \& Werni, S. (2019). Gambaran Faktor Penyebab Rujukan DI Puskesmas Kota Depok. http://dx.doi.org/10.22435/hsr.v22i3.512

Peraturan Menteri Kesehatan Republik Indonesia Nomor 001 Tahun 2012 Tentang Sistem Rujukan Pelayanan Kesehatan Perorangan.

Peraturan Menteri Kesehatan Republik Indonesia Nomor 19 Tahun 2016 Tentang Sistem Penanggulangan Gawat Darurat Terpadu

Silvalila, M. (2019). Pelayanan Ambulan Udara di Provinsi Aceh. Jurnal Kedokteran Nanggroe Medika, 2(1), 35-40.

Zaenab, Z. L. T. S. N. Problem dan Tantangan Puskesmas dan Rumah Sakit Umum Daerah dalam Mendukung Sistem Rujukan Maternal di Kabupaten Karimun Provinsi Kepri Tahun 2012. Jurnal Kebijakan Kesehatan Indonesia: JKKI 